\title{
210 ベクトルカレントビューアによる電流分布の可視化
}

\author{
廣田 章博 ${ }^{\circ}$, 早野 誠治, 斉藤 兆古（法政大学）
}

堀井 清之（白百合女子大学）

\author{
Current Visualization by Vector Current Viewer \\ Akihiro HIROTA, Seiji HAYANO, Yoshifuru SAITO and Kiyoshi HORII
}

\begin{abstract}
In recent years, $\mathrm{PCBs}$ (Printed Circuit Boards) are widely employed to work out the compact as well as lightweight electrical devices. However, inspection of their regularity is not so simple because of their complex electric circuit structures. One of the non-destructive tests to do that is to measure in the vicinity the electromagnetic fields essentially accompanying with their operation. Estimating the field sources from the measured fields becomes useful and important information not only for checking up their regularity but also for the EMC/EMI problems. According to this background, we are motivated to propose the current viewer, which makes it possible to visualize the current distributions in PCBs.

Previously, we have proposed the current viewer in order to visualize the current distribution on planar electric circuits. Operation principle of this current viewer is based on those of modified Rogowski coil method. The mechanical structure of this viewer is that the sensor solenoid coils does not cover all the circumferences of the target current carrying conductor, but covers a semicircle. In this paper, we propose the vector current viewer by combining two current viewers in orthogonal way, Our vector current viewer is capable of visualizing the magnitude as well as direction of target current along with the Lissajous diagram methodology.
\end{abstract}

Keywords: Current viewer, Current distribution, Printed circuit boards

\section{1. まえがき}

近年, 電子機器の小型軽量化を実現する方途として, 電気・電子回路を印刷技術で構成するプリント基板が開 発され，広汎に用いられている，結果として，精緻な電 気・電子回路が平面上に実現され, 高度な半導体集積回 路の開発に伴って極めて小型軽量な電子機器の普及に繋 がった。他方，産業廃棄物が社会問題となる中で，プリ ント基板は精緻な回路を実装するために故障診断が不可 能に近く，不良となった基板は廃棄されるのが通例であ る. また, 回路の健全性の検査工程においても人間の目 視検査がせいぜいである。しかしながら，故障箇所が特 定可能で有れば，修復も可能であり，また，プリント基 板の信頼性向上にも繫がる.

このような現状を鑑み，本論文は平面上に存在する電 流分布を直接可視化するベクトルカレントビューアを提 案する、ベクトルカレントビューアは, 電流の大きさお よびその経路を可視化し，視覚的に電流分布状態の把握
を可能とすることで, 故障診断や回路の健全性を評価可 能とする。基本的な原理は，通常磁界測定に用いられる ソレノイド型コイル型センサーでなく電流の流れる銅線 の半周を覆う円弧状の変形ロゴスキーコイル（以下カレ ントビューア）をセンサーコイルとして採用する，カレ ントビューアは，アンペアの法則に基づき，平面状に分 布した電流位置を推定する場合, ソレノイド型のサーチ コイルよりも高感度に電流の作る磁界を効果的に測定可 能とする．カレントビューアは平面の電流分布を測定す るために, X, Y 方向に 2 回の走査と測定が必要である. 本稿で提案するベクトルカレントビューアは, 平面上 を 1 回の走查で X, Y 方向の磁界を同時に測定可能と寸 るセンサーである。 また，カレントビューアでは平面に 分布寸る電流から得られる信号を処理し，電流の可視化 を行うが，ベクトルカレントビューアでは，X，Y 方向 の出力電圧をそれぞれオシロスコープの横軸・縦軸に入 カして得られるリサージュ図形を描かせることで，リア ルタイムで電流経路を可視化する. 


\section{2. ベクトルカレントビューア}

\section{1 センサーの形状}

通常, 磁界測定ではループ状のソレノイドコイルを用 いて高解像度を実現しようとする場合, 巻き数を増加し 断面積を小さくする必要がある。これは, 磁界源となる 電流は線上に存在するが, ソレノイドコイルはコイル面 に鎖交する磁束を測定する必要性に起因する，筆者等の グループは線上に存在する電流の位置推定精度の向上を 図るため, 形状が半円弧状のカレントビューアを提案し た 1) -4).

このカレントビューアは大電流計測に用いられるロゴスキ 一コイルを部分的に利用する円弧状構造である. カレントビ ューアはFig. 1 (a) に示すように直線電流に対して平行 方向にコイルを走査した場合, 電流位置にセンサーが到 達すると電流から生じる鎖交磁束数が最大となり, 出力 も最大となる。しかし，Fig. 1(b)のように直線電流に対 して垂直方向にコイルを走査しても磁束が鎖交しないた め, センサー出力は得られない, 従って, カレントビュ 一アは電流分布に対して平行方向のみの電流による磁界 を検出するため, 平行 ・垂直方向の出力信号間で直交性 が成り立つ。

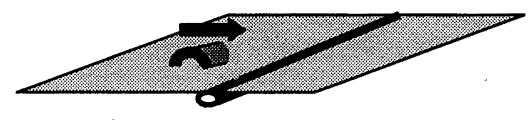

Fig. 1 (a) Current Viewer Set in Parallel to a Current Carrying Conductor

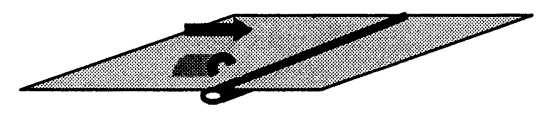

Fig. 1 (b) Current Viewer Set in Perpendicular to a Current Carrying Conductor

ここでカレントビューアを互いに直交させたセンサーが本 論文で提案寸るベクトルカレントビューアである. Fig. 2 に試 作したベクトルカレントビューアを示す.

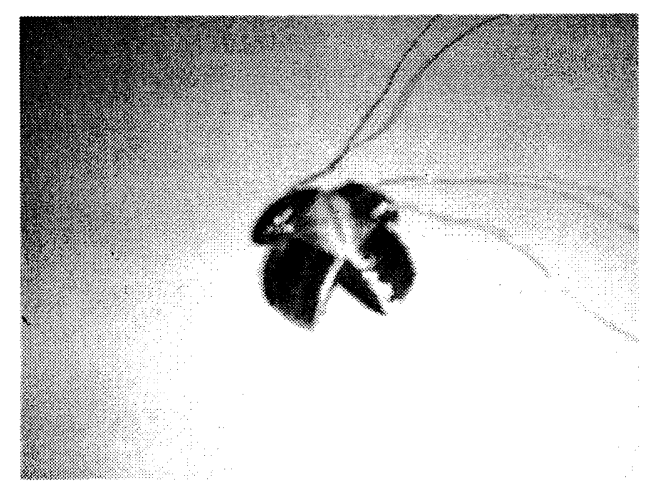

Fig. 2 Tested Vector Current Viewer

\section{2 カレントビューアの動作原理}

複数個の角型コイルを組み合わせた同心円状のサーチ コイルで構成されたカレントビューアは, アンペアの周 回積分の法則を直接利用するロゴスキーコイルを部分的 に取り出した形状であり，センシング部分は電流が流れ る導線を覆う構造となっている。このため, カレントビ ユーアはプリント基板表面で, 電流の作る磁界をコイル で囲むことなく効果的に測定可能とする磁気センサーで ある。

カレントビューアの動作原理をFig. 3 を用いて説明す る. カレントビューアを通電中の直線導体近傍で水平に 走査した場合, センサーと導体中心が一致する時点で電 流の作る磁界は半円弧状のコイルに鎖交する.しかし， センサーと導体の中心がずれた場所に位置する場合, 電 流 $\mathrm{i}$ の作る磁界 $\mathrm{H}$ は半円弧状のコイルの局所部分にのみ 鎖交する，拠って，電流の位置推定度が向上する。

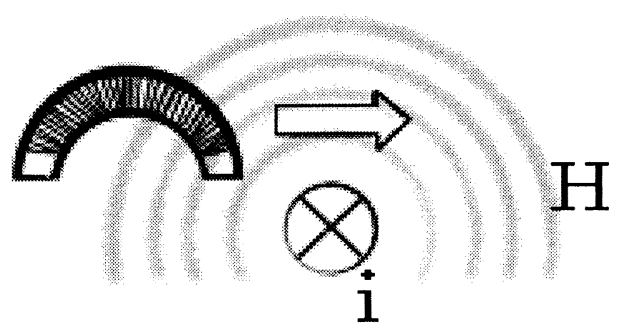

Fig. 3 Current Searching by Current Viewer

2.3 カレントビューアの出カ

カレントビューアの鎖交磁束計算法について述べる.

Fig. 4 に示すように, 無限に長い直線導体に電流 $i$ が流 れている場合, 導線を含む平面内で長さ 1 の辺を導線軸 に平行とし, 軸からの距離が $b$ の位置にある長方形の部 分を通る磁束を考える.

線軸から $r$ の距離に幅 $d r$ の微小面積 $d S$ を通る磁束は (1)式で与えられる.

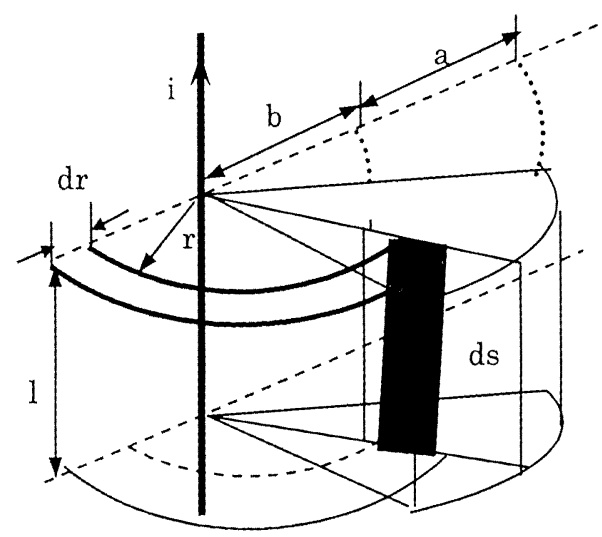

Fig. 4 Various Constants of Current Viewer for Sensor Output Calculation 


$$
d \phi=\mu_{0} H d S
$$

ここで $\mu_{0}$ は真空中の透磁率である、 $\mathrm{r}$ 点での磁界は(2) 式のアンペアの法則で与えられ，

$$
H=\frac{i}{2 \pi r}
$$

$d S=l \cdot d r$ より微小面積 $S$ を通る磁束は(3)式で与えられる.

$$
d \phi=\frac{\mu_{0} i l}{2 \pi r} d r
$$

よって長方形を通る磁束は(4)式となる.

$$
\Phi=\int_{b}^{b+a} d \phi=\int_{b}^{b+a} \frac{\mu_{0} i l}{2 \pi r} d r
$$

電流がサーチコイルアレイの中心にある場合, 長方形 のコイルを貫く磁束は(4)式から求められ, 角型コイルの 個数を $N$ とした鎖交磁束数 $\lambda$ は $N \Phi$ である. よって, センサー出力の誘起電圧はファラデーの法則より(5)式 で表される。

$$
v=-N \frac{d \Phi}{d t}
$$

電流 I の位置が円弧の中心からずれた場合は，(4)式の 解析的な積分が困難であるため，(4)式を数值積分して全 鎖交磁束数を求める.

\section{3. 電流分布推定}

3.1 ベクトルカレントビューアの校正

本論文の実験では, Fig. 2 で示したベクトルカレント ビューアを用いた．その仕様をTable 1 に示す.

Table 1 Specification of One of the Tested Vector

\begin{tabular}{|c|c|c|c|}
\hline $\begin{array}{c}\text { 半径 } \mathrm{r} \\
{[\mathrm{mm}]}\end{array}$ & $\begin{array}{c}\text { Current Viewer } \\
{[\mathrm{mm}]}\end{array}$ & $\begin{array}{c}\text { 長さ } 1 \\
{[\mathrm{~mm}]}\end{array}$ & $\begin{array}{c}\text { 巻き数 } \mathrm{N} \\
{[\text { turn }]}\end{array}$ \\
\hline 15 & 1.5 & 10 & 200 \\
\hline
\end{tabular}

本実験は供試ベクトルカレントビューアの指向性と精 度を評価し，X，Y 軸方向出力の校正データを得るため に行う。

$10 \mathrm{kHz}, 0.5 \mathrm{~A}$ の電流を通電している直線導体上に, 供 試ベクトルカレントビューアの中心を位置し, ベクトル カレントビューアの中心を軸として, 直線導体に対して カレントビューアを $0,45,90 ， 135 ， 180$ と 225 度さ らに 270 度に回転させて $\mathrm{X}, \mathrm{Y}$ 方向の出力電圧をそれぞ れオシロスコープの横軸・縦軸に入カしリサージュ図形 を得る。
この実験で，0 と 180 度，45 と 225 度，90 と 270 度 のリサージュ図が同じならば, 供試ベクトルカレントビ ューアは, 互いに直交する 2 個のカレントビューアの出 力が同等であり, 高精度な機械的構造と評価できる. 実 際の実験結果をFig. 5 に示寸. Fig. 5 から，Y 軸方向の カレントビューアは 0 度と 180 度で幅が異なり多少の指 向性を持つことが判る.さらに, X 軸方向も 90 度と 270 度で幅が異なり，多少の指向性を有することが判る。こ れらの指向性を利用して最終結果を校正することとする。

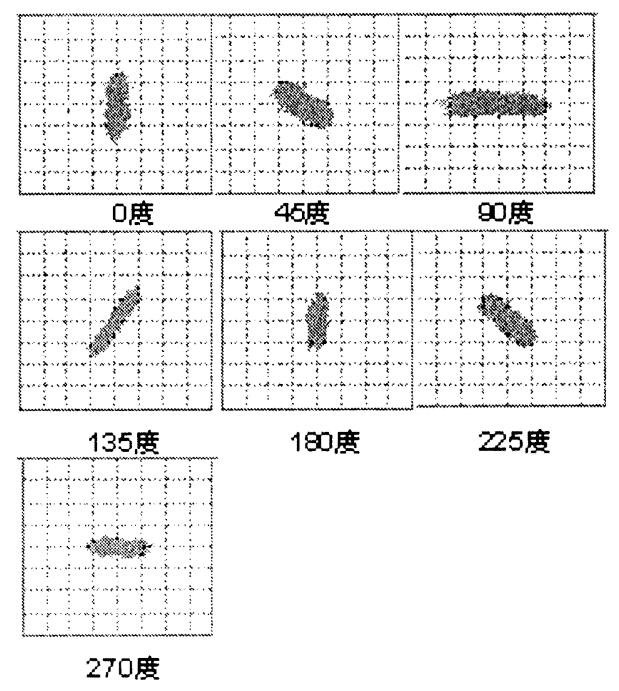

Fig. 5 Lissajous Diagram at Each of Vector Current Viewer Angles

\section{2 電流探査実験}

カレントビューアの電流位置推定精度は, サーチコイ ル直径程度が限界であることが報告されている ${ }^{4)}$ ，その ため, 正方形 (一辺 $30 \mathrm{~mm} \times 30 \mathrm{~mm}$ ) の Fig. 6 に示寸供 試電気回路を構成し， $10 \mathrm{kHz} ， 0.5 \mathrm{~A}$ の電流を通電する. 正方形上を等間隔に X, Y 方向, それぞれ 10 点測定し, 合計 100 点でベクトルカレントビューアの出力を観測し た. 各点でのベクトルカレントビューアの $\mathrm{X}, \mathrm{Y}$ 方向の 出力をFig. 7 と Fig. 8 に示す.

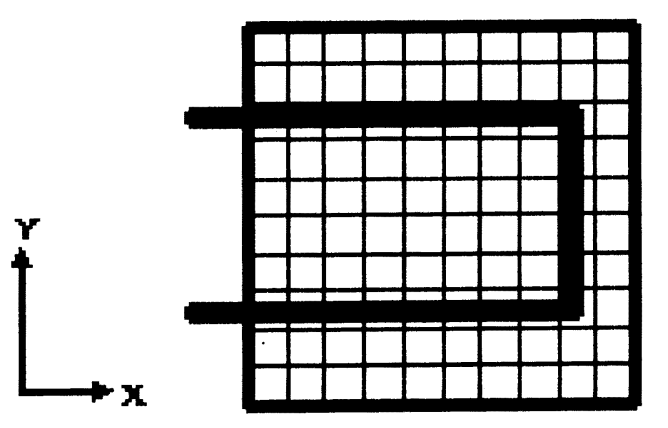

Fig. 6 Electric Current Model for Current Distribution Tracing 

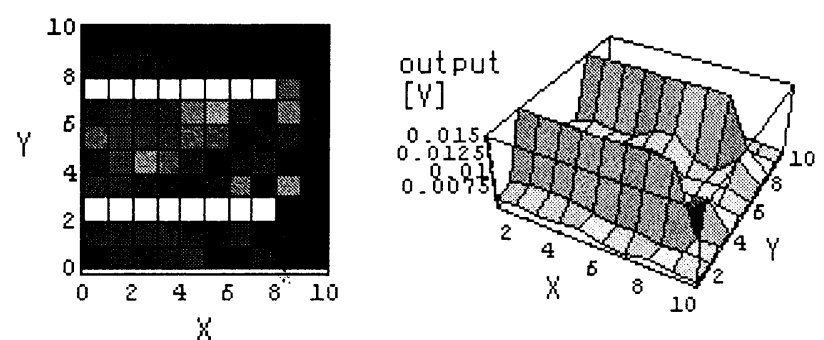

Fig. 7 Output Signal Distribution of X Direction
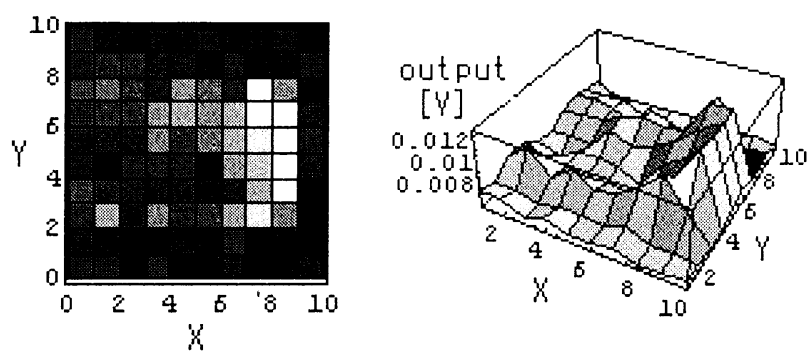

Fig. 8 Output Signal Distribution of Y Direction

従来型のカレントビューアの場合， $\mathrm{X} ， \mathrm{Y}$ それぞれの 方向ヘスキャンする必要が有るが, ベクトルカレントビ ユーアを用いた場合, Fig. 7 と Fig. 8 の結果が 1 回のス キャンで得られる。 さらに, ベクトルカレントビューア を正方平面上で走査することにより，Fig. 5 に示すリサ ージュ図形から直接に電流の大きさと通電方向をリアル タイムで可視化可能である原理がここで検証された。

検査対象となる PCB の寸法が固定されている場合, $\mathrm{PCB}$ の寸法に合わせてベクトルカレントビューアを所 望の精度に必要な個数を配置し, 個々のベクトルカレン トビューア出力を $\mathrm{AD}$ コンバータを介して計算機に入力 し, 予め 3.1 節で得た校正デー夕を用いて校正し, 計算 機ディスプレイへ表示寸れば，瞬時に PCB の健全性が 可視化情報として評価可能な非破壊検査システムが構成 可能であろう。

\section{4. まとめ}

従来型のカレントビューアでは, 平面の磁界分布を測 定する場合, $\mathrm{X}, \mathrm{Y}$ 軸方向へ 2 回の走查が必要であり, さらに, X, Y 軸方向の測定值を個々に組み合わせて電 流分布を可視化した. そのためリアルタイムでの電流分 布可視化は困難であった.

この問題を解決するため, 本論文は, 単一センサーに $\mathrm{X}, \mathrm{Y}$ 方向の電流を同時に測定可能とする変形ロゴスキ ーコイルを直交して配置したベクトルカレントビューア を提案した。

最終的には検查対象となる $\mathrm{PCB}$ の寸法に合わせてべ クトルカレントビュワーを所望の精度に必要な個数を配

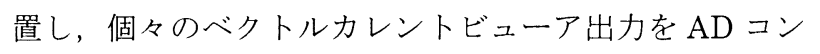
バータを介して計算機に入力し，予为測定しておいた校
正データを用いて個々の出力を校正し，計算機ディスプ レイヘサージュ図形を物理的ベクトルカレントビューア の配置と同一に表示寸ることで, 瞬時に PCB の健全性 が可視化情報として評価可能な非破壊検査システムを構 築するのが本研究の目的である.

本論文では, 上記非破壊検査システムの原理検証実験 を主として検討した. その結果, $\mathrm{PCB}$ の非破壊検查法と して期待できることが判明した。

\section{参 考 文 献}

1）青木誠, 斎藤兆古：変形ロゴスキーコイルを用いた 電流分布推定, 法政大学計算科学研究センタ一研究報 告, (2000), 第 13 巻.

2）青木誠, 斎藤兆古, 早野誠治：カレントビューアによる二 次元電流分布の測定, 電気学会マグネティックス研究 会資料， (1999)，MAG-98-113.

3）青木誠, 斎藤兆古, 早野誠治 他 : カレントビューアの開 発一基礎原理と実験一, 電気学会マグネティックス研 究会資料，(1998），MAG-98-113.

4）青木誠, 斎藤兆古, 早野誠治 ： カレントビューアに関寸る 研究一その 2 電流分布のデコンボリューションー, 電 気学会マグネティックス研究会資料, (1998), MAG-98-265. 